\title{
Perempuan dan Politik: Studi Komunikasi Politik tentang Keterwakilan Perempuan di Legislatif
}

\author{
Zaenal Mukarom
}

\begin{abstract}
In order to encourage women's active role to participate in political world, especially to meet the demand of Electoral Regulation, a portion of $30 \%$ electoral committee was dedicated as minimum allocation for women. To meet those demands, a political communication strategy was needed. The strategy could be implemented by women themselves, or political party. Women political communication strategy was carried out by applying a counter of political communication: gender mainstreaming, affirmative action, political education for women, and civic education for women. Meanwhile, political parties conducted their political communication by utilizing media and message strategy. Message strategy was implemented by employing political marketing mix consisted of product, promotion, price, and place. Media strategy appeared by diffusion of innovation approach by emphasizing gender mainstreaming issues among public.
\end{abstract}

Kata kunci: partisipasi politik, gender, patriarki

\section{Pendahuluan}

Kesadaran politik perempuan berdasarkan sejarah Indonesia telah tumbuh sejak Kongres Perempuan pertama di Yogyakarta 1928. Kesadaran politik dalam bentuk partisipasi nyata dan penggunaan hak-hak politik perempuan tercermin pula pada Pemilu 1955 di mana mereka memiliki hak memilih dan dipilih. Pengakuan yang sama hakhak perempuan dengan laki-laki dalam kehidupan berbangsa dan bernegara di Indonesia telah diakui secara tegas. Pengakuan tersebut ditetapkan melalui berbagai instrumen hukum dan dengan meratifikasi berbagai konvensi yang menjamin hakhak politik mereka.

Undang-Undang RI No. 39 tahun 1999 tentang HAM, pasal 6, menyebutkan bahwa sistem pemilihan umum, kepartaian, pemilihan anggota badan legislatif dan sistem pengangkatan di bidang eksekutif dan yudikatif harus menjadikan keterwakilan perempuan sesuai dengan persyaratan yang ditentukan. Penegasan hak politik perempuan ini juga dibuktikan dengan diratifikasinya Konvensi Hak-Hak Politik Perempuan (Convention on the Political Right of Women) serta penghapusan segala bentuk diskriminasi terhadap perempuan (Convention on the Elimination of all forms of Discrimination againts Women) melalui Undang-Undang No.7 tahun 1984 (Sihite, 2007:138).

Namun, kendati berbagai perangkat hukum telah melegitimasi partisipasi politik bagi 
perempuan sampai saat ini antara perempuan dengan dunia politik masih merupakan dua hal yang tidak mudah dipertautkan satu dengan lainnya. Hal ini dibuktikan dengan keterwakilan perempuan di panggung politik dan lembaga politik formal jumlahnya masih sangat rendah dibandingkan laki-laki. Dalam lembaga legislatif keterwakilan perempuan amat kecil, tidak seimbang dengan jumlah mereka. Keterbatasan partisipasi perempuan ini memengaruhi, baik secara langsung maupun tidak langsung, terhadap upaya pemberdayaan perempuan.

UU Pemilu No.12/2004 sebenarnya telah mengisyaratkan adanya alokasi minimum sebesar $30 \%$ kepada perempuan untuk duduk di lembaga legislatif. Ini bisa dilihat dalam pasal 65 , ayat 1 , yang berbunyi:

"Setiap partai politik dapat mengajukan calon anggota DPR, DPRD Propinsi dan DPRD Kabupaten/Kota untuk setiap daerah pemilihan dengan memperhatikan keterwakilan perempuan sekurang-kurangnya 30 persen."

UU pemilu tersebut secara tidak langsung merupakan salah satu bentuk akomodasi politik atas tuntutan pentingnya kesetaraan gender bagi kalangan perempuan dalam wilayah politik, sekaligus memberikan ruang partisipasi politik yang lebih besar bagi perempuan dalam pembangunan bangsa. Perempuan memiliki hak yang sama dengan laki-laki untuk berpartisipasi di berbagai bidang kehidupan. Apalagi berkaitan dengan politik yang mengurus hajat hidup orang banyak, termasuk kaum perempuan itu sendiri. Representasi perempuan yang memadai di lembaga legislatif akan sangat dibutuhkan. Hal ini bisa dilihat dalam kondisi legislatif masa sebelumnya di mana keterwakilan perempuan sangat minim sehingga mengakibatkan kepentingan kaum perempuan menjadi terabaikan. Kuota 30\% keterwakilan perempuan ini diharapkan mampu mengeliminasi hal tersebut dan memberikan kesempatan kepada kaum perempuan untuk terlibat lebih banyak di ranah politik.

Namun dalam realitasnya, Undang-undang ini sepertinya belum diterapkan secara maksimal. Hal ini terjadi karena pengaturan mengenai kuota $30 \%$ ini merupakan hal yang baru dalam dunia politik Indonesia, sehingga masih banyak pengurus partai politik yang belum memahaminya sesuai dengan yang diamanatkan oleh undang-undang tersebut. Selain itu, juga ketatnya persaingan memperebutkan kursi dewan menyebabkan keterwakilan perempuan mengikuti mekanisme persaingan alamiah.

\section{Partisipasi Politik Perempuan}

Sebelum membahas tentang partisipasi politik perempuan, terlebih dahulu perlu didefinisikan istilah partisipasi, partisipasi politik, dan partisipasi politik perempuan, serta keterwakilan mereka di parlemen.

Partisipasi secara bahasa diartikan sebagai pengambilan bagian atau pengikutsertaan. Partisipasi sangat penting bagi pembangunan diri dan kemandirian warga negara. Melalui partisipasi, individu menjadi warga publik, dan mampu membedakan persoalan pribadi dengan persoalan masyarakat. Tanpa partisipasi, hampir semua orang akan dikuasai oleh kepentingan pribadi dan pemuasan kebutuhan pribadi mereka yang berkuasa.

Adapun partisipasi politik, menurut McClosky (1972:52), adalah kegiatan-kegiatan sukarela dari warga masyarakat melalui hal mana mereka mengambil bagian dalam proses pemilihan penguasa, dan secara langsung atau tidak langsung, berpartisipasi dalam proses pembuatan kebijakan umum.

Miriam Budiardjo (1998) mendefinisikan partisipasi politik sebagai pengejawantahan dari penyelenggaraan kekuasaan politik yang absah oleh rakyat. Anggota masyarakat yang berpartisipasi dalam proses politik melalui pemilu terdorong oleh keyakinan bahwa melalui kegiatan bersama itu kepentingan mereka akan tersalurkan, atau sekurang-kurangnya diperhatikan. Dengan kata lain, mereka percaya bahwa kegiatan mereka memiliki efek, dan efek tersebut dinamakan political effifacy.

Di bawah ini bentuk piramida partisipasi politik yang menggambarkan hierarki partisipasi politik menurut Roth dan Wilson (1980: 151-152): 
Berdasarkan gambar di atas, dapat diketahui bahwa partisipasi politik merupakan suatu kegiatan seseorang atau sekelompok orang yang turut serta secara aktif dalam kehidupan politik dengan jalan memilih pimpinan negara dan secara langsung atau tidak langsung memengaruhi kebijakan nasional. Menurut Roth dan Wilson (1980: 151-152), kegiatan partisipasi politik secara konvensional mencakup tindakan:

(1) Memberikan suara dalam pemilihan umum (voting);

(2) Menghadiri rapat umum (campaign);

(3) Menjadi anggota suatu partai atau kelompok kepentingan;

(4) Mengadakan komunikasi dengan pejabat pemerintah, atau anggota parlemen.

Sedangkan kegiatan partisipasi politik yang berbentuk non-konvensional, berupa:

(1) Pengajuan petisi (tuntutan);
(2) Melakukan demonstrasi (seruan bersama di jalanan);

(3) Melakukan konfrontasi (perlawanan);

(4) Melakukan mogok (non action).

Adapun Rush (1997:124) menjelaskan bentukbentuk partisipasi politik adalah sebagai berikut:

(1) Menduduki jabatan politik atau administrasi;

(2) Mencari jabatan politik atau administrasi;

(3) Keanggotaan aktif suatu organisasi politik;

(4) Keanggotaan pasif suatu organisasi politik;

(5) Keanggotaan aktif suatu organisasi semu politik;

(6) Keanggotaan pasif suatu organisasi semu politik;

(7) Partisipasi dalam rapat umum, demonstrasi, dan lain sebagainyn;

(8) Partisipasi dalam diskusi politik informal;

(9) Voting (pemberian suara)

(10) Apathis total.

Gambar 1

Piramida Partisipasi Politik

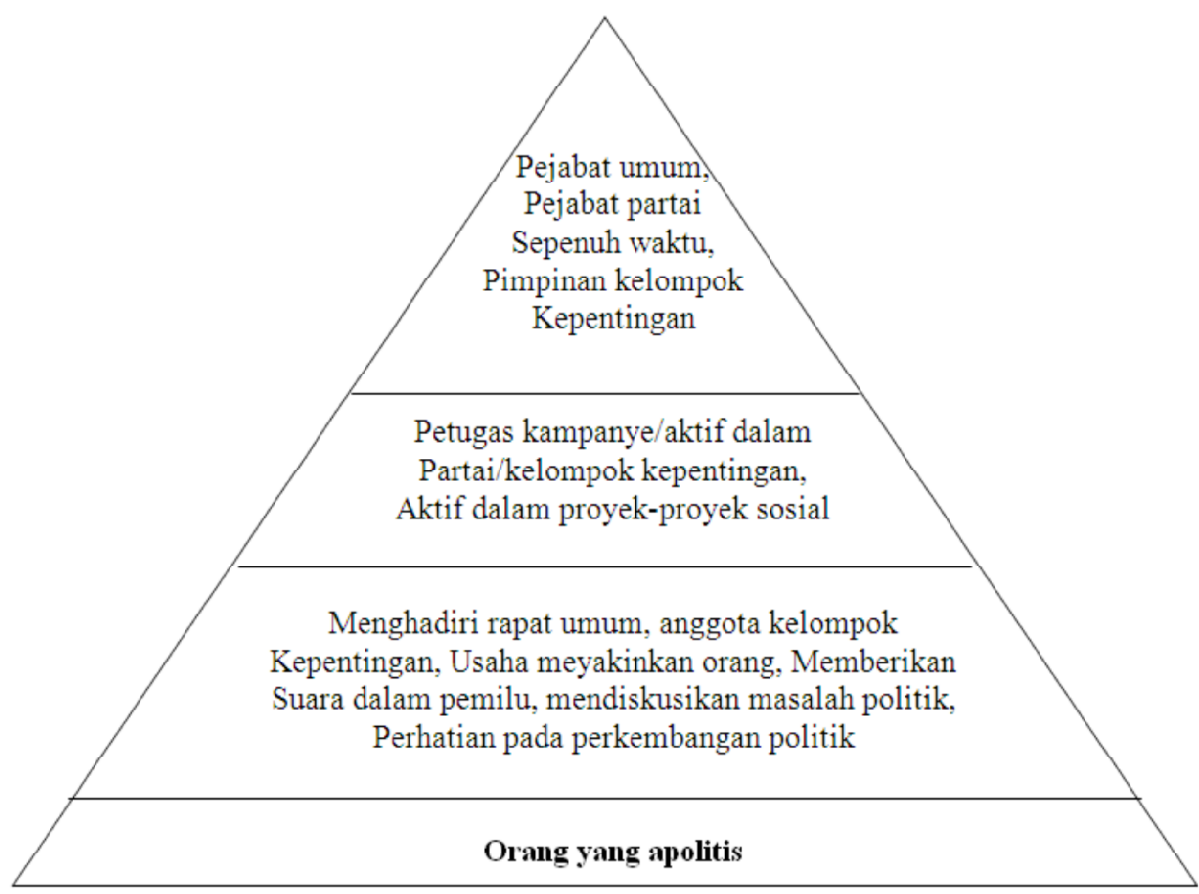

Zaenal Mukarom. Perempuan dan Politik: Studi Komunikasi Politik tentang Keterwakilan Perempuan ... 259 
Sedangkan Rosenau dalam Nimmo (200:47) membagi partisipasi politik ke dalam dua kategori warga negara yang merupakan khalayak dari partisipasi dalam komunikasi politik, yaitu: pertama adalah orang-orang yang sangat memperhatikan politik, kedua adalah orang-orang yang hanya dimobilisasi untuk kepentingan politik. Selanjutnya, menurut Nimmo (2000:47) keterlibatan seseorang dalam partisipasi politik dipengaruhi oleh faktor-faktor:

(1) Peluang resmi, artinya ada kesempatan seseorang terlibat dalam partisipasi politik karena didukung kebijakan-kebijakan yang dibuat oleh negara;

(2) Sumber Daya Sosial, artinya partisipasi ditentukan oleh kelas sosial dan perbedaan geografis. Dalam kenyataannya tidak semua orang memiliki peluang yang sama berkenaan dengan sumberdaya sosial dan sumberdaya ekonomi untuk terlibat dalam partisipasi politik. Berkaitan dengan perbedaan geografis, terdapat juga perbedaan dalam partisipasi seperti usia, jenis kelamin, suku, tempat tinggal, agama, dll;

(3) Motivasi Personal, artinya motif yang mendasari kegiatan berpolitik sangat bervariasi. Motif ini bisa sengaja atau tidak disengaja, rasional atau tidak rasional, diilhami psikologis atau sosial, diarahkan dari dalam diri sendiri atau dari luar, dan dipikirkan atau tidak dipikirkan.

Berdasarkan pengertian partisipasi politik di atas, maka bisa diketahui bahwa partisipasi politik perempuan bisa berbentuk konvensional dan bisa juga non-konvensional. Hanya memang kemudian partisipasi perempuan ini dipengaruhi oleh peluang resmi, apakah perempuan diberikan kesempatan untuk berada di wilayah politik tersebut, sumber daya sosial yang berarti apakah mereka memiliki kemampuan untuk terjun ke wilayah tersebut dan motivasi personal atau kemauan dari perempuan untuk terlibat aktif di dalamnya.

Partisipasi politik perempuan berdasarkan pengkategorian Milbarth terdiri atas: (1) apatis, yaitu tidak aktif, dan menarik diri dari proses politik;
(2) spectator, yaitu pernah memilih dalam pemilihan umum; (3) gladiator, yaitu terlibat dalam proses politik; dan (4) pengeritik, yaitu dalam bentuk partisipasi tidak konvensional. Sedangkan menurut Olsen partisipasi politik termasuk di dalamnya perempuan yaitu: (1) pemimpin politik; (2) aktivis politik; (3) komunikator; (4) warga negara biasa; (5) marginal; dan (6) orang yang terisolasi (Surbahdi, 1999:143).

Melihat tinggi rendahnya kesadaran politik dan kepercayaan terhadap pemerintah, mengikuti pembagian Paige (1971), partisipasi politik perempuan bisa dibagi ke dalam empat tipe, yaitu:

(1) Aktif, yaitu apabila seseorang memiliki kesadaran politik, dan kepercayaan kepada pemerintah tinggi;

(2) Apatis (pasif-tertekan), yaitu apabila kesadaran politik dan kepercayaan kepada pemerintah rendah;

(3) Militan radikal, yaitu apabila kesadaran politik tinggi, kepercayaan kepada pemerintah sangat rendah;

(4) Pasif, yaitu apabila kesadaran politik rendah, dan kepercayaan kepada pemerintah sangat tinggi.

Dalam menjalankan partisipasinya perempuan mendapatkan banyak kendala. Menurut Lycette (1994:42) terdapat paling sedikit empat kendala bagi perempuan dalam berpartisipasi di bidang politik, yaitu disebabkan karena:

(1) Perempuan menjalankan dua peran sekaligus, yaitu peran reproduktif dan peran produktif, di dalam maupun di luar rumah;

(2) Perempuan relatif memiliki pendidikan yang rendah dibanding dengan laki-laki karena perbedaan kesempatan yang diperoleh;

(3) Adanya hambatan budaya yang terkait dengan pembagian kerja secara seksual dan pola interaksi perempuan dengan laki-laki yang membatasi gerak perempuan;

(4) Adanya hambatan legal bagi perempuan, seperti larangan kepemilikan tanah, larangan berpartisipasi dalam pendidikan atau program Keluarga Berencana tanpa persetujuan dari suami atau ayahnya. 
Terakreditasi Dirjen Dikti SK No. 56/DIKTI/Kep/2005

Menurut hasil penelitian tentang partisipasi politik perempuan di negara-negara berkembang, ada kecenderungan rendah dibandingkan laki-laki. Pasalnya, mereka lebih banyak terlibat dalam urusan rumah tangga atau domestik. Memang diakui bahwa ada beberapa keterbatasan bagi perempuan untuk berkiprah dalam dunia politik. Tiga di antaranya yang menonjol yaitu, pertama, aspek supply and demand. Supply berkaitan dengan faktor-faktor prinsipal yang menentukan kemampuan politik perempuan. Demand merupakan faktor institusional dan politis yang berkaitan dengan masalah rekruitmen politik bagi perempuan. Antara supply dan demand ini tidak saling bergantung karena perempuan bisa saja mengantisipasi kesulitan-kesulitan praktis dalam mengombinasikan peran-peran domestiknya dengan jabatan-jabatan politik.

Kedua, keterbatasan kemampuan perempuan dalam dunia politik erat kaitannya dengan masalah sosialisasi politik. Sosialisasi politik cenderung menggiring perempuan untuk mendapatkan status tertentu tanpa usahanya sendiri (ascribe status). Githesen and Prestage mengatakan bahwa masalah yang dihadapi perempuan dalam dunia politik mencakup ketegangan antara ascribe status dan achieved status yang merupakan akibat proses sosialisasi politik.

Ketiga, faktor yang bersifat situasional yang meliputi masalah yang bersifat keibuan. Tanggung jawab pada anak-anak di rumah, tampaknya merupakan rintangan paling serius bagi perempuan untuk membuka akses dalam meraih jabatanjabatan politis dan pemerintahan. Selain itu, masalah krusial lain adalah perempuan bekerja tidak memiliki banyak waktu yang tersisa, sehingga ada ketidakmungkinan menerima jabatan politik tertentu. Keadaan itu menyebabkan bentuk partisipasi politik perempuan menjadi noninstitusional.

Di antara bentuk partisipasi nyata perempuan adalah dengan melihat keterwakilan mereka di panggung politik dan lembaga politik formal. Secara realitas, ternyata di Indonesia jumlah perwakilan perempuan masih sangat rendah dibandingkan laki-laki. Dalam lembaga legislative, keterwakilan perempuan amat kecil, tidak seimbang dengan jumlah mereka.

Kecilnya keterwakilan perempuan ini bisa dilihat di DPRD Kota Bandung di mana anggota legislatif perempuan masa kerja 2004-2009, hanya 6 orang dari total 45 orang $(13,3 \%)$. Padahal, penduduk kota Bandung berdasarkan hasil Susenas tahun 2003 adalah 2.228.268 jiwa, dengan jumlah perempuan 1.113.267 jiwa, atau 49,96\%, dan penduduk laki-laki 1.115.001 jiwa, atau 50,04\%(BPS, 2003). Ini menunjukkan bahwa jumlah perempuan yang besar dari penduduk tidak tampak dalam jumlah keterwakilan di lembaga legislatif.

Ketimpangan perwakilan perempuan ini bukan

Tabel 1

Komposisi Anggota DPRD Kota Bandung 2004-2009

\begin{tabular}{|l|c|c|c|}
\hline \multicolumn{1}{|c|}{ Fraksi } & Perempuan & Laki-laki & Jumlah \\
\hline PKS & 2 & 9 & 11 \\
\hline PDIP & 2 & 8 & 10 \\
\hline Partai Demokrat & 1 & 5 & 6 \\
\hline Partai Golkar & 1 & 5 & 6 \\
\hline PAN & - & 6 & 6 \\
\hline Persatuan Bintang & - & 6 & 6 \\
\hline Jumlah Total & $\mathbf{6}$ & $\mathbf{3 9}$ & $\mathbf{4 5}$ \\
\hline
\end{tabular}

Sumber: www.bandung.go.id

Zaenal Mukarom. Perempuan dan Politik: Studi Komunikasi Politik tentang Keterwakilan Perempuan ... 261 
Tabel 2

Tingkat Representasi Perempuan dalam Lembaga Legislatif

\begin{tabular}{|c|c|c|}
\hline Masa kerja & Perempuan & Laki-laki \\
\hline $1950-1955(\mathrm{DPRS})$ & $9(3.8 \%)$ & $236(96.2 \%)$ \\
\hline $1955-1960$ & $17(6.3 \%)$ & $272(93.7 \%)$ \\
\hline $1956-1959$ & $25(5.1 \%)$ & $488(94.9 \%)$ \\
\hline $1971-1977$ & $36(7.8 \%)$ & $460(92.2 \%)$ \\
\hline $1977-1982$ & $29(6.3 \%)$ & $460(93.7 \%)$ \\
\hline $1982-1987$ & $39(8.5 \%)$ & $460(91.5 \%)$ \\
\hline $1987-1992$ & $65(13 \%)$ & $500(87 \%)$ \\
\hline $1992-1997$ & $62(12.5 \%)$ & $500(87.5 \%)$ \\
\hline $1997-1999$ & $54(10.8 \%)$ & $500(59.2 \%)$ \\
\hline $1999-2004$ & $46(9 \%)$ & $500(91 \%)$ \\
\hline $2004-2009$ & $65(11.8 \%)$ & $485(88,2 \%)$ \\
\hline
\end{tabular}

Sumber : www.cetro.or.id

hanya terjadi di daerah, tetapi juga di tingkat nasional. Kalau ditelusuri semenjak tahun 1950 sampai pemilu 2004, tidak ada perubahan yang signifikan. Peningkatan muncul pada periode 19871992, sebanyak $13 \%$, tetapi justru setelah periode tersebut terus mengalami penurunan sampai dengan periode 2004-2009 menjadi $11,8 \%$ sebagaimana tercermin pada tabel 2 .

Cetro pernah mengungkapkan bahwa masalah minimnya keterwakilan perempuan, pada dasarnya didorong oleh upaya-upaya sistematis atau kesengajaan dari berbagai pihak. Para pengurus partai politik mungkin sengaja menempatkan perempuan pada urutan tertentu, sehingga mengecilkan kemungkinan calon legislatif perempuan untuk dapat duduk di lembaga legislatif (Jurnal Perempuan, 2003). Di samping itu, juga masih minimnya perempuan yang terjun di dunia politik, baik secara kuantitas maupun kualitas, menyebabkan kemungkinan calon legislatif perempuan untuk duduk di lembaga legislatif semakin mengecil. Minimnya calon legislatif dari perempuan merupakan fenomena yang telah lama terjadi di Indonesia.

Demikian pula dalam masalah partisipasi politik perempuan. Sebuah pengamatan mengungkapkan bahwa perempuan yang terjun ke dalam kegiatan politik dan mendapat jabatan politik dapat diklasifikasikan menjadi tiga kelompok. Kelompok pertama adalah perempuan yang memeroleh jabatan politik karena mereka memiliki hubungan dengan laki-laki tertentu. Misalnya, suaminya eksekutif, sang istri duduk di dewan. Ayahnya duduk di legislatif, putrinya dikader untuk duduk di legislatif. Ayahnya memiliki reputasi sosial politik, sehingga putrinya dianggap dan diposisikan cukup mampu menjadi anggota dewan.

Kelompok kedua adalah perempuan yang terjun ke dunia politik setelah bebas tugas dalam membesarkan anak-anaknya. Hal itu menyebabkan usia karier politiknya menjadi lebih pendek. Kelompok ketiga adalah perempuan yang dalam usia muda 30-an terjun dalam politik. Biasanya, mereka telah cukup lama aktif dalam dunia ormas, LSM, atau organisasi ekstra kampus. Mereka inilah yang termasuk jenis politisi perempuan profesional karier yang jumlahnya paling sedikit akibat proses sosialisasi, pendidikan, dan rekruitmen politik perempuan yang tidak berakar dan berjalan secara sistematis. 


\section{Budaya Politik}

Realitas sosial yang menggambarkan kecenderungan minimumnya partisipasi politik perempuan dan rendahnya keterwakilan mereka dalam legislatif tentu dipengaruhi oleh banyak factor. Salah satu faktor yang disinyalir amat kuat pengaruhnya adalah budaya politik.

Budaya politik lahir dari budaya bangsa yang ada dalam masyarakat. Budaya bangsa merupakan cerminan pola hidup masyarakat yang tinggal di daerah tersebut. Budaya yang dominan di Indonesia adalah budaya patrimonialistik. Menurut Gaffar (2004:115) budaya patrimonialistik adalah budaya di mana pemerintah ada di bawah kontrol seseorang dan kelompoknya. Budaya patrimonialistik ini memiliki karakteristik: (1) kecenderungan untuk memperkuat sumberdaya yang dimiliki seorang penguasa kepada temantemannya; (2) kebijaksanaan seringkali bersifat partikularistik daripada bersifat universalistik; (3) rule of law, merupakan sesuatu yang bersifat sekunder bila dibandingkan dengan kekuasaan dari seorang penguasa (rule of man); dan (4) kalangan penguasa politik seringkali mengaburkan antara mana yang menyangkut kepentingan umum dan mana yang menyangkut kepentingan publik. Budaya yang dianut oleh masyarakat ini sangat menentukan orientasi dan partisipasi masyarakat dan orientasi inilah yang menyebabkan tidak banyak perempuan yang mau menjadi calon legislatif.

Selain itu, masyarakat Indonesia juga dikenal sebagai masyarakat yang kuat budaya Patriarki, yaitu menempatkan perempuan pada posisi yang selalu berada di bawah laki-laki. Murniati (2004:8) mendefinisikan patriarki sebagai suatu sistem yang bercirikan laki-laki (ayah). Dalam sistem ini, lakilaki yang berkuasa untuk menentukan segala sesuatu yang akan dilakukan atau tidak dilakukan. Sistem ini dianggap wajar sebab pembenarannya disejajarkan dengan pembagian kerja berdasarkan seks atau jenis kelamin dan bukan berdasarkan gender.

Di samping itu, Murniti (2004:171) juga mengungkapkan, ada yang meyakini bahwa budaya patriarki merupakan suatu sistem yang bertingkat, yang telah dibentuk oleh suatu kekuasaan yang mengkontrol dan mendominasi pihak lain. Pihak lain in menurut yang meyakini definisi tersebut adalah kelompok miskin, lemah, rendah, tidak berdaya, juga lingkungan hidup dan perempuan.

Dalam budaya patriarki, negara yang menganut budaya tersebut disebut patriarkis. Dalam ungkapan Saraswati (2004:31), patriarkis adalah negara yang mempromosikan dan memelihara praktek-praktek yang secara langsung dan sistematis menindas perempuan. Penindasan perempuan dilihat dari struktur keluarga dan rumah tangga serta kebijaksanaannya yang diterapkan pada kedua bidang tersebut. Biasanya, kebijakan tersebut bersifat diskriminatif, atau menghambat status kebebasan dan ekonomi bagi perempuan.

Lebih lanjut Murniati (2004:118) mengungkapkan kelemahan-kelemahan perempuan akibat budaya patriarki adalah:

(1) Perempuan kurang menyadari bahwa dirinya adalah seorang pribadi yang mempunyai hakhak azasi manusia yang sama;

(2) Perempuan seringkali kesulitan menghilangkan perasaan malu dan perasaan takut salah;

(3) Perempuan kurang mampu berpikir jenih dan logis, sehingga sulit dalam mengambil keputusan;

(4) Perempuan memiliki beban kerja domestik;

(5) Perempuan selalu mempertimbangkan faktor keluarga, atau tradisi turun temurun keluarga yang aktif di organisasi;

(6) Perempuan selalu mempertimbangkan faktor kesamaan agama;

(7) Perempuan selalu mempertimbangkan faktor ekonomi;

(8) Perempuan kurang dapat menerima kekuasaan (yang dipercayakan) dan dalam merebut kekuasaan lebih suka mengalah;

(9) Perempuan kurang mampu mengendalikan emosi, sehingga pikirannya kurang stabil dan mudah terpengaruh;

(10) Perempuan tidak mampu menjalin persatuan yang solid, sehingga mudah terceraiberai dan sukar menyatukan pandangan; 
(11) Perempuan kurang berminat untuk bekerja keras;

(12) Perempuan seringkali lebih suka tergantung pada laki-laki dari pada hidup secara mandiri;

(13) Perempuan selalu mempertimbangkan dan tergantung pada figur atau kharisma pemimpin organisasi.

Budaya patriarki menempatkan perempuan pada posisi yang lebih mengutamakan peran-peran domestik. Perempuan dibebani tanggung jawab yang lebih besar dalam pengurusan rumah tangga (home maker), perawatan, pengasuhan dan pendidikan anak dan penjaga moral (Sihite, 2007:138). Kegiatan perempuan sebagai pencari nafkah (breed winner), terlibat aktif dalam komunitas organisasi dan partai politik hanya dianggap sebagai peran sekunder (Mukarom, 2004).

Kuatnya pengaruh budaya bangsa ini pada politik lambat laun membentuk budaya politik yang kemudian menjadi cara pandang dan persepsi masyarakat mengenai politik. Politik selalu dihubungkan dengan hal-hal yang bersifat maskulin yang dianggap kontras dengan sifat-sifat keperempuanan yang feminin. Perempuan dianggap tidak cocok untuk terjun di dunia politik yang keras karena menganggap bahwa perempuan memiliki watak yang lemah lembut, tidak kuat, dan tidak tegas. Perempuan juga dianggap tidak akan mampu menjadi pimpinan sebuah organisasi, partai politik atau pemerintahan. Banyak perempuan yang memiliki pendidikan dan kemampuan yang tinggi, tetapi karena terikat dengan budaya patriarki ini, mereka tidak berminat terjun dalam dunia politik termasuk menjadi calon anggota legislatif.

Dalam sistem budaya patriarki, laki-laki dianggap lebih sesuai untuk terjun di dunia politik. Peran laki-laki sebagai kepala rumah tangga, pengambil keputusan, dan pencari nafkah (bread winner), sesuai dengan arena politik yang sarat dengan peran pengambil kebijakan dan isu-isu kekuasaan. Rata-rata yang dipilih adalah laki-laki, karena laki-lakilah yang selama ini melakukan upaya-upaya pemberdayaan politik (Wijaya, 2001:20).
Budaya ini menciptakan pandangan yang timpang tentang relasi perempuan dan laki-laki. Dalam situasi semacam ini, menurut Widyani (Widyani, 2005:183) gender sebagai budaya berproses menjadi ideologi. Maka ideologi gender diwarnai oleh budaya patriarki. Relasi timpang yang didasarkan kekuasaan laki-laki atas perempuan menimbulkan ketidakadilan gender.

Nilai patriarki ini dijelaskan dengan teori gender yang melihat perbedaan perempuan dan lakilaki dari segi biologi yang dipandang sebagai hal yang menyebabkan perbedaan peran gender dalam kehidupan yang lebih luas, yaitu kehidupan social (Sumiarni, 2004:9). Teori gender membawa angin baru setidaknya memengaruhi cara pandang orang dalam melihat relasi laki-laki dan perempuan. Dengan teori ini, laki-laki dan perempuan memiliki hak dan kedudukan yang sama dalam semua bidang kehidupan.

Dalam gender, terdapat teori hukum alam (nature) yang menyatakan bahwa perbedaan peran antara laki-laki dan perempuan ditentukan oleh jenis kelamin mereka. Teori ini membagi dua peran yang sangat berbeda bagi perempuan dan laki-laki. Menurut teori ini, berbagai hormon yang dibentuk oleh tubuh perempuan dan laki-laki telah membuat laki-laki berbeda dengan perempuan. Misalnya, perbedaan hormonal dalam tubuh mengakibatkan laki-laki yang memiliki hormon testosteron menjadi lebih agresif dibandingkan perempuan, sedangkan perempuan diidentikkan dengan peran domestiknya karena sifat keibuannya yang dianggap sebagai kodrat.

Asumsi teori hukum alam (nature) yang dijelaskan di atas, memperkuat berbagai budaya yang merendahkan perempuan. Ada label stereotype (citra baku) yang ditanamkan kepada kaum perempuan. Terdapat citra baku yang melekat pada peran, fungsi, dan tanggung jawab, yang membedakan antara laki-laki dan perempuan dalam keluarga dan masyarakat. Cara berpikir stereotype tentang peran gender ini sangat mendalam merasuki mayoritas masyarakat (Bunga Rampai, 2003:91).

Lebih lanjut Widyani (2005:185) mengungkapkan bentuk-bentuk ketidakadilan gender dalam 
Terakreditasi Dirjen Dikti SK No. 56/DIKTI/Kep/2005

keluarga sebagai hasil dari ideologi gender adalah:

(1) Ketidakadilan yang muncul karena memandang posisi perempuan sub-ordinat. Pandangan ini antara lain menciptakan sikap suami berkuasa atas istri dan merasa memiliki tubuh istri. Sikap kuasa mengakibatkan pelecehan kepada istri dan anak perempuan. Mereka dipandang sebagai manusia yang tidak mampu berpikir dan tidak diajak bicara untuk mengambil keputusan. Lebih mendahulukan anak laki-laki untuk mendapatkan fasilitas keluarga (biaya sekolah) daripada anak perempuan, sehingga perempuan dalam memeroleh pendidikan pun cenderung dinomorduakan.

(2) Pembagian kerja berdasarkan seks atau membetuk stereotype terhadap anggota keluarga. Wujud dari ketidakadilan ini apabila pembagian kerja dalam keluarga berdasarkan seks adalah pekerjaan rumah dibebankan kepada istri dan anak perempuan, sedangkan anak laki-laki diberi tugas keluar. Anak lakilaki tidak boleh menangis atau anak perempuan tidak boleh pulang malam. Pandangan stereotype ini mengakibatkan anggota keluarga (perempuan) tidak dapat menjadi dirinya atau kehilangan jati dirinya, karena konstruksi sosial dalam keluarga tidak sesuai dengan jati dirinya. Kemampuan pribadi perempuan tidak dihargai dan tidak dinilai;

(3) Beban ganda yang dialami perempuan dalam keluarga. Apabila istri bekerja di luar rumah, masih harus dibebani pekerjaan rumah, ia mengalami beban ganda. Ketidakadilan terjadi apabila istri dan anak perempuan dibebani tuga luar rumah dan dalam rumah. Sedangkan suami dan anak laki-laki hanya menanggung beban tugas di luar rumah saja. Pembagian kerja yang berdasarkan jenis kelamin akan mengakibaktan beban ganda bahkan berlipat-lipat terhadap perempuan.

(4) Marjinalisasi terhadap perempuan. Ketidakadilan ini terwujud apabila pendapat istri dan anak perempuan tidak pernah didengar dan dihargai. Mereka tidak mempunyai hak bersuara dan berpendapat dalam mengambil keputusan keluarga. Istri atau anak perempuan tidak diberi kesempatan untuk menambah pengetahuan dan keterampilannya, mereka tidak boleh menjadi pemimpin atau kepala keluarga;

(5) Kekerasan terhadap perempuan. Dari semua ketidakadilan tersebut di atas, muaranya sampai pada kekerasan terhadap perempuan. Kekerasan ini bisa berupa fisik, misalnya pemukulan, pemerkosaan terhadap istri (pemaksaan baik kasar maupun halus untuk berhubungan suami-istri), penganiayaan, dan pembunuhan. Kekerasan psikis terjadi apabila istri atau anak perempuan mendapat teror, ancaman, intimidasi, dan tekanan atau kontrol yang berlebihan dari suami atau saudara lakilaki. Kekerasan spiritual terjadi apabila seseorang dipaksa untuk meyakini yang sebenarnya dia tidak yakini. Hal ini merupakan pemaksaan di bidang agama dan kepercayaan.

Budaya politik ini juga sangat kuat pengaruhnya kepada orientasi politik masyarakat terutama partai politik dalam perekrutan kader dan penjaringan calon legislatif. Orientasi politik memegang peran penting dalam penjaringan calon legislatif, baik di tingkat pusat maupun di daerah. Dengan adanya persepsi negatif tentang perempuan dalam dunia politik mengakibatkan orientasi politik perempuan juga negatif dan akibatnya perempuan marjinal dalam komposisi calon legislatif. Sebaliknya, calon legislatiflaki-laki karena dipersepsi positif menyebabkan jumlah mereka dominan di dalamnya.

\section{Strategi Komunikasi Politik}

Berdasarkan aturan perundang-undangan partisipasi politik perempuan sangat dilindungi bahkan diberikan kemudahan. UU Pemilu No.12/ 2004 telah mengisyaratkan adanya alokasi minimum sebesar 30\% kepada perempuan untuk duduk di lembaga legislatif. Tuntutan UU berupa affirmative action yang memberi akses pada perempuan duduk di parlemen melalui pelaksanaan kuota minimum $30 \%$ tidak bisa dilepaskan dari strategi komunikasi. 
Strategi menurut Kamus Umum Bahasa Indonesia, WJS Poerwadarminta (1986) adalah siasat perang atau juga bisa dikatakan akal atau tipu muslihat untuk mencapai sesuatu. Sedangkan menurut M. Dahlan (1995:964) strategi merupakan rencana yang cermat mengenai kegiatan untuk mencapai sasaran khusus.

Definisi strategi yang memperlihatkan hubungan strategi dengan komunikasi politik dikemukakan oleh Effendy (1993:300). Menurutnya, strategi dapat diartikan sebagai suatu seni pendistribusian dan penggunaan alat-alat (bisnis) untuk memenuhi hasil akhir sebuah kebijakan. Selain itu, strategi juga dapat didefinisikan sebagai ilmu pengetahuan dan seni dalam menghadapi dan mengkoordinasikan sumber daya-sumber daya untuk mencapai tujuan.

Keberhasilan suatu kegiatan komunikasi banyak ditentukan oleh strategi komunikasinya. Strategi pada hakikatnya adalah perencanaan (planning) dan manajemen (management) untuk mencapai suatu tujuan. Tetapi, untuk mencapai tujuan tersebut, strategi tidak hanya berfungsi sebagai peta jalan yang hanya menunjukkan arah saja, melainkan harus menunjukkan bagaimana taktik operasionalnya.

Strategi komunikasi dalam kaitan dengan partisipasi perempuan dan keterwakilan mereka di lembaga legislatifbisa dikelompokkan menjadi dua, yaitu strategi komunikasi politik perempuan dan strategi komunikasi politik partai politik.

Strategi komunikasi perempuan dilakukan melalui counter komunikasi politik. Counter komunikasi politik ini tentu saja bukan hanya dilakukan oleh politisi perempuan tapi juga harus melibatkan politisi laki-laki.

Upaya counter komunikasi politik yang pertama yang perlu dilakukan oleh perempuan adalah dengan pengarusutamaan gender (gender mainstream). Hal ini didasarkan pada Inpres No. 9 tahun 2000, yang mendorong perhatian masalah gender untuk semakin ditingkatkan. Dengan pemahaman perspektif gender dan sensitif gender di kalangan pengambil kebijakan seperti badan eksekutif dan lembaga legislatif juga terus dikembangkan, sehingga berbagai kebijakan dan instrumen hukum yang berbasis kepentingan perempuan mulai terwujud.

Pengarusutamaan gender merupakan strategi untuk mencapai kesetaraan dan keadilan gender. Menurutnya, pengarusutamaan gender bertujuan untuk memastikan apakah perempuan dan laki-laki memeroleh akses kepada, berpartisipasi dalam, mempunyai kotrol atas, dan memeroleh manfaat yang sama dari pembangunan.

Counter komunikasi politik yang kedua yaitu dengan mendorong affirmative action, sehingga amanat UU pemilu Nomor 20 tahun 2004 tentang keterwakilan perempuan minimal $30 \%$ itu direalisasikan dengan sebaik-baiknya. Berbagai kegiatan bisa dilakukan oleh kaum perempuan, yaitu dengan mengadakan seminar, lokakarya, kajian ilmiah tentang affirmative action.

Counter komunikasi politik yang ketiga yaitu dengan melakukan pendidikan politik kepada perempuan. Upaya paling awal agar perempuan siap berkompetisi di dunia publik tentu saja dengan mencerdaskan kaum perempuan, sehingga mereka memiliki pengetahuan-pengetahuan dasar tentang politik yang selanjutnya mereka bisa aktif sejajar dengan kaum laki-laki di dunia politik. Di antara cara melakukan pendidikan politik dari kalangan perempuan adalah dengan mendirikan organisasiorganisasi khusus perempuan. Melalui organisasi ini kemudian perempuan diberi kesempatan untuk berkompetisi dengan sesama perempuan lagi. Berbagai posisi strategis bisa diduduki oleh kalangan perempuan sehingga mereka terampil dan ahli dalam menyelesaikan masalah berkaitan dengan posisi strategis manapun.

Pendidikan politik perempuan melalui organisasi mendorong mereka untuk semakin aktif ikut serta di dalam kegiatan-kegiatan yang sifatnya publik. Perempuan bisa tampil lebih terbuka dan mampu menyuarakan aspirasinya berkaitan dengan berbagai isu sosial kemasyarakatan. Hambatanhambatan psikologis dieliminasi sedemikian rupa, sehingga aktivis-aktivis muda perempuan bermunculan. Dari sini kemudian muncul harapan untuk bertambahnya aktivis politik perempuan baik secara kuantitatif maupun kualitatif.

Namun, pendidikan politik tidak cukup dari 
Terakreditasi Dirjen Dikti SK No. 56/DIKTI/Kep/2005

organisasi keperempuanan saja, dibutuhkan pula kegiatan-kegiatan khusus yang sifatnya insidentil untuk menambah wawasan dan keahlian kaum perempuan, misalnya melalui kegiatan-kegiatan ilmiah. Seminar, diskusi, simposium, atau pelatihan kepemimpinan adalah kegiatan-kegiatan berguna yang dapat menjadi counter komunikasi politik. Dengan kegiatan-kegiatan tersebut perempuan akan memiliki kemampuan untuk memiliki wawasan berpolitik yang lebih luas dan lebih baik. Mereka akan terasah dalam menyelesaikan berbagai masalah sosial kemasyarakatan dan siap terjun karena memiliki kemampuan yang tidak kalah dibandingkan kaum laki-laki.

Pendidikan politik juga bisa dilakukan melalui civic education, atau pendidikan kewarganegaraan, yang berisi tentang pendidikan hak-hak politik perempuan, dan hak-hak sipil mereka yang selama ini terabaikan. Ini dilakukan melalui penyuluhan, seminar, atau forum-forum ilmiah lainnya yang menyebarluaskan nilai-nilai egaliter, dan kemandirian dalam kehidupan sosial pada institusi formal maupun nonformal yang kemudian mendorong perempuan untuk tampil percaya diri di panggung politik.

Penanggung jawab pendidikan politik bagi kaum perempuan ini, apalagi dikaitkan dengan pemenuhan kuota minimum $30 \%$ perempuan di parlemen selain kaum perempuan tentu saja adalah partai politik. Partai politiklah yang seharusnya paling terdepan dalam mendidik kaum perempuan sehingga mereka mampu tampil dan aktif di dunia politik. Hal ini terutama berupa pembukaan akses yang lebih luas dengan mendistribusikan perempuan dalam posisi-posisi strategis di organisasi.

Partai politik sebagai mana pandangan Miriam Budiardjo (1998:3) menyelenggarakan 4 (empat) fungsi, yaitu: komunikasi politik, sosialiasai politik, rekruitmen politik, dan pengatur konflik. Keempat fungsi ini menjadi barometer fungsional bagi partai politik di masyarakat. Berkenaan dengan itu, sosialisasi UU pemilu yang mensyaratkan keterwakilan perempuan $30 \%$ di lembaga legislatif akan diukur sejauhmana strategi komunikasi politik partai politik dalam mensosialisasikan UU tersebut.
Partai politik tersebut harus memiliki komitmen yang kuat untuk memperjuangkan aspirasi kaum perempuan, sekaligus kepentingan masyarakat secara umum. Di sinilah kemudian partai politik harus membuat strategi komunikasi politik dalam menjembatani partisipasi politik perempuan.

Strategi komunikasi yang bisa dibangun oleh partai politik adalah dengan menggunakan strategi pesan dan strategi media (Firmanzaah: 2007: 59). Strategi pesan adalah pengemasan pesan politik untuk mengarahkan pemaknaan masyarakat terhadapnya. Pesan politik harus mampu membuka dan mengungkapkan tentang masalah yang sedang dihadapi masyarakat. Pesan tersebut juga tidak hanya merupakan wacana, tetapi juga mengandung cara memecahkan. Ini berarti masalah keterwakilan perempuan $30 \%$ di lembaga legislatif perlu dikemas oleh partai politik menjadi pesan yang menarik berdasarkan data dan informasi yang akurat, sehingga masyarakat memerhatikan dengan baik. Adapun partai politik membangun strategi komunikasi politik berupa kaderisasi, pemberdayaan perempuan dan bauran marketing.

Strategi pesan dilakukan partai politik melalui kaderisasi. Artinya, pesan-pesan politik banyak berisi ajakan agar perempuan semakin aktif dalam dunia politik seperti menjadi anggota partai. Strategi yang dilakukan partai adalah dengan menggunakan strategi media, yaitu melalui sosialisasi perempuan dalam berbagai media termasuk dalam kepengurusan struktural. Perempuan akan mampu tampil di dunia poitik bila diberi kesempatan untuk menduduki posisi strategis dan kemudian juga diketahui oleh umum.

Sedangkan strategi komunikasi politik partai berkaitan dengan marketing politik yaitu marketing mix (bauran marketing) yang terdiri dari : Product (produk), Promotion (promosi), Price (harga), dan Place (penempatan). Product yang dilakukan oleh partai politiknya adalah dengan mempersiapkan politisi perempuan yang berkualitas dan dikenal di masyarakat untuk dijadikan caleg. Karakterisik personal dari politis perempuan ini tentu saja sangat dipengaruhi oleh berbagai faktor termasuk pengaruh dari patron-client seperti keluarga atau suami. Semua faktor 
tersebut menjadi nilai tambah bagi politisi perempuan untuk berkiprah dalam dunia politik.

Sedangkan Promosi (promotion) dilakukan dengan cara mengaktifkan para politisi perempuan dalam berbagai kegiatan. Di masyarakat, caleg perempuan juga dipublikasikan secara gencar melalui kegiatan-kegiatan sosial kemasyarakatan, seperti diaktifkan dalam kegiatan keagamaan, majelis taklim, atau kegiatan ibu-ibu. Price (harga) yang berarti persiapan daya dukung ekonomi untuk meloloskan politisi perempuan menjadi anggota legislatif. Kebutuhan dana yang besar biasanya harus ada untuk melakukan aktivitas politik terutama kampanye dan proses penentuan internal caleg di parpol. Dengan dukungan dana partisipasi politik dan keterwakilan perempuan di legislatif semakin didorong. Adapun Penempatan (place), artinya penempatan arti politisi perempuan sebagai caleg dengan ditempatkan pada posisi yang strategis, yaitu diurutan nomor jadi di bagian paling pertama atau kedua.

Sedangkan strategi komunikasi politik partai politik dilakukan melalui media. Strategi ini dilakukan dengan pemilihan media yang sesuai untuk menyampaikan pesan-pesan politik. Media tidak selamanya sebagai saluran yang menggambarkan perempuan secara negatif. Media juga mampu mengangkat posisi perempuan sederajat dengan laki-laki bila digunakan sebagai media strategi komunikasi. Penyampaian pesan politik melalui media sangat tepat menggunakan teori difusi inovasi. Everet M. Rogers (Effendy, 1993: 284) mendefinisikan difusi inovasi sebagai proses di mana suatu inovasi dikomunikasikan melalui saluran tertentu dalam jangka waktu tertentu diantara para anggota suatu sistem sosial. Difusi melakukan penyebaran pesan-pesan sebagai ide baru.

Dengan difusi inovasi ini, media mengangkat isu pengarusutamaan gender (gender mainstream) termasuk di dalamnya partisipasi perempuan dalam politik berupa keterwakilan secara proporsional. Isu partisipasi perempuan merupakan inovasi baru dalam masyarakat yang disebarluaskan oleh media. Dengan mengangkat isu keterwakilan perempuan ini memberikan pengetahuan (knowl- edge), persuasi dan peneguhan (confirmation) kepada masyarakat tentang pentingnya perempuan dalam dunia politik.

\section{Penutup}

Demikianlah partisipasi perempuan di wilayah politik perlu diupayakan dengan memaksimalkan dan memberdayakan perempuan itu sendiri, selain juga strategi komunikasi politik yang jitu, sehingga perempuan bisa maksimal berpartisipasi, termasuk mendapatkan perwakilan di legislatif yang sesuai dengan jumlah mereka di masyarakat.

Keterbatasan partisipasi perempuan akan sangat memengaruhi, baik secara langsung maupun tidak langsung, terhadap upaya pengembangan masyarakat, termasuk juga pemberdayaan perempuan. Jika tingkat partisipasi politik masyarakat termasuk di dalamnya perempuan rendah, maka ada indikasi bahwa pelaksanaan demokrasi yang dilaksanakan di suatu negara memberi tanda yang kurang baik. Dan hal tersebut tentu saja akan sangat merugikan bagi bangsa dan negara.

\section{Daftar Pustaka}

Budiardjo Miriam. 1998. Dasar-Dasar Ilmu Politik. Jakarta: Gramedia.

Bunga Rampai. 2003. Bahan Pembelajaran Pelatihan Pengarusutamaan Gender dalam Program Pembangunan Nasional.

Dahlan M. 1995. dkk.Kamus Induk Istilah Ilmiah. Surabaya: Target Press.

Effendy Onong Uchjana. 1993. Ilmu, Teori dan Filsafat Komunikasi. Bandung: Citra Aditya Bakti.

Firmanzah. 2007. Marketing Politik: Antara Pemahaman dan Realitas. Jakarta: Buku Obor.

Gaffar Afan. 2004. Politik Indonesia, Transisi Menuju Demokrasi. Yogyakarta: Pustaka Pelajar 2000 
Margaret Lycette, Adjusting Project to Overcome Constrant on Women Participation Forum. USAID. 1994

McClosky, Herbert. 1972. Political Participation: International Encyclopedia of the social Sciences. New York: MacMillan company and The Free Press.

Mukarom Zaenal. 2004. Makalah pada kegiatan sosialiasi peningkatan partisipasi perempuan dalam politik, "Kerangka Acuan Peningkatan peran Perempuan di Bidang Politik Menuju keterwakilan Perempuan $30 \%$ dalam Pemilu 2004. Korpri Jawa Barat.

Murniati. 2004. Getar Gender, Perempuan dalam perspektif Agama Budaya dan Kelaurga. Magelang: Tera.

Nimmo, Dan. 2000. Political Communication and Public Opinion. California: Goodyear Publishing Company.
Roth dan Wilson. 1980. The Comparative Study of Politic. New York: Prencite Hall Inc.

Rush dan Althoff. 1997. Pengantar Sosial Politik. Jakarta: Raja Grafindo.

Saraswati Tumbu. 2004. Agenda Perjuangan Politik Perempuan melalui Parlemen. Jurnal Perempuan No. 37.

Sihite Romany. 2007. Perempuan, Kesetaraan, Keadilan: Suatu Tinjauan Berwawasan Gender. Jakarta: Raja Grafindo.

Sumiarni Endang. 2004. Gender dan Feminisme. Yogyakarta: Wonderful Publishing Company.

Surbakti Ramlan. 1999. Memahami Ilmu Politik. Jakarta: Gramedia.

Widyani Agnes. 2005. Hukum berkeadilan Gender. Jakarta: Kompas.

Wijaya Hesti. 2001. Perempuan dalam Pusaran Demokrasi. Bantul: IP-4 Lapera. 
